\title{
A postresuscitatiós ellátás neuroprotekciós lehetőségei 2019-ben
}

\author{
Kovács Enikő dr. ${ }^{1}$ - Gál János dr. ${ }^{1}$ - Merkely Béla dr. ${ }^{2}$ - Zima Endre dr. ${ }^{2}$ \\ 'Semmelweis Egyetem, Általános Orvostudományi Kar, Aneszteziológiai és Intenzív Terápiás Klinika, Budapest \\ ${ }^{2}$ Semmelweis Egyetem, Általános Orvostudományi Kar, Városmajori Szív- és Érgyógyászati Klinika, Budapest
}

\begin{abstract}
A postresuscitatiós terápia egyik legfontosabb eleme a neuroprotekció, mivel a sikeres újraélesztésen átesett betegek fó mortalitási tényezője a postresuscitatiós agyi károsodás. A tudomány mai állása szerint a jelenleg elérhető neuroprotekciós módszerek célja, hogy megelőzzék a primer agykárosodás kiterjedését és a szekunder agykárosodás kialakulását. Közleményünkben részletezzük a ma rendelkezésre álló neuroprotekciós lehetőségeket, külön kitérve az egyes farmakológiai ágensek és ezen belül a szedáció szerepére, az agyi perfúzió fenntartásának lehetőségeire, a megfelelő hemodinamikai paraméterek monitorozására és kiválasztására, valamint a célhőmérséklet-orientált kezelésre. A postresuscitatiós betegek ellátása során fontos, hogy kerüljük a hypoxiát és hyperoxiát, normocapniára és normoglykaemiára törekedjünk, valamint a görcstevékenységet azonnal uraljuk. Egyelőre nincs még egyértelmü bizonyíték arra vonatkozóan, hogy melyik gyógyszer alkalmazása segíthet a postresuscitatiós neuroprotekcióban. A tiamin ez irányú vizsgálata során biztató eredmények születtek. Az agyi perfúzió javítása céljából fontos lehet a magasabb szintű hemodinamikai monitorozás és az általa vezérelt terápia, de ennek bizonyítása szintén további tanulmányok elvégzését igényli. A postresuscitatiós neuroprotekció fő elemét a célhőmérséklet-orientált kezelés képezi, kivitelezésének részletei azonban szintén számos kérdést vetnek fel.
\end{abstract}

Orv Hetil. 2019; 160(46): 1832-1839.

Kulcsszavak: újraélesztés, neuroprotekció, agyi károsodás

\section{Possibilities of post-resuscitation neuroprotection in 2019}

Post-resuscitation brain injury forms the leading cause of death of patients after successful cardiopulmonary resuscitation that explains why post-resuscitation neuroprotection is the most important part of post-resuscitation therapy. The goals of the neuroprotection tools available today are preventing the evolution of primary and formation of secondary brain injury. We are going to summarize the neuroprotective possibilities that we can reach today. We will discuss the role of pharmacologic strategies including sedation, the modalities of upholding brain perfusion, the monitoring of proper hemodynamic variables and the practice of targeted temperature management. It is very important to avoid hypo- and hyperoxia, to keep normocapnia, normoglycemia and to control seizures during the management of post-cardiac arrest patients. There is still a lack of evidence to prove which pharmacologic agent may be effective in postresuscitation neuroprotection, however, there are some promising results regarding thiamine. Hemodynamic management guided by higher level hemodynamic monitoring may be beneficial in enhancing brain perfusion but more clinical studies are needed to investigate its usefulness. Targeted temperature management constitutes the main element of post-resuscitation neuroprotection, however, the details of its implementation raise several questions.

Keywords: cardiopulmonary resuscitation, neuroprotection, brain injury

Kovács E, Gál J, Merkely B, Zima E. [Possibilities of post-resuscitation neuroprotection in 2019]. Orv Hetil. 2019; 160(46): 1832-1839.

(Beérkezett: 2019. július 21.; elfogadva: 2019. szeptember 4.)

\section{Rövidítések}

$\mathrm{CI}=($ cardiac index $)$ szívindex $; \mathrm{CPC}=($ cerebral performance category) az agyi teljesítmény kategóriája; EEG = elektroencefalográfia; $\mathrm{PiCCO}^{\mathrm{TM}}=($ Pulse index Contour Cardiac Output $)$ pulzusindexkontúr-perctérfogat; SVRI = (systemic vascular resistance index) szisztémás vascularis ellenállási index; TTM = (targeted temperature management) célhőmérséklet-orientált kezelés 
A hirtelen szívhalál ma az egyik vezető halálok Európában [1]. Prognózisa még mindig rossz, annak ellenére, hogy egyre nagyobb hangsúlyt helyezünk a túlélési lánc elemeinek erôsítésére és a keringésmegállás ellátásának javítására. A kórházon kívüli keringésmegállást szenvedett betegek csupán 7-10\%-a, a kórházon belüli újraélesztésen átesett betegek kb. 25\%-a hagyja el élve a kórházat [1].

A túlélési lánc elemei határozzák meg, hogy mely lépéseket kell megtennünk annak érdekében, hogy újraélesztési kísérletünk sikeres legyen [2]. A túlélési lánc negyedik láncszeme a hatékony postresuscitatiós terápia, mely a keringés visszatérte utáni lépéseket foglalja magában. A postresuscitatiós ellátás fontosságát jelzi, hogy a Magyar Resuscitatiós Társaság és az Európai Resuscitatiós Tanács (European Resuscitation Council) által 2015ben kiadott irányelvekben külön fejezet foglalkozik a keringés visszatérte után jelentkező szindróma kezelési lépéseivel $[3,4]$.

A postresuscitatiós terápia során az egyik legnagyobb kihívást és mortalitási tényezőt továbbra is a postresuscitatiós agyi károsodás jelenti, melynek előfordulási gyakorisága kórházon kívüli keringésmegállást követően 68\%, míg kórházon belüli újraélesztés után 25\% [5]. Ezek az adatok azt vetítik elö, hogy a terápia során az egyik legfontosabb dolgunk az újraélesztés alatt kialakult primer agyi károsodás mérséklése (amennyiben mód van erre), illetve a szekunder agykárosodás megelőzése.

Összefoglalónk fó célja, hogy a ma rendelkezésre álló, klinikumban használatos vagy épp még vizsgált neuroprotekciós eljárásokról átfogó képet nyújtson, és segítse a klinikusokat abban, hogy ezeknek az eljárásoknak a miértjét és mikéntjét minél inkább megértsék. Az 1. táblázat összefoglalja a közleményben részletezett neuroprotekciós lehetőségeket és terápiás javaslatokat.

\section{Postresuscitatiós szindróma}

A keringés visszatérte után komplex szindróma lép fel, mely az alábbi összetevőkből áll:

- postresuscitatiós agyi károsodás,

- postresuscitatiós szívizom-károsodás,

- ischaemiás-reperfúziós szindróma,

- a keringésmegállást kiváltó patológiás elváltozás.

A sikeresen újraélesztett betegek körében a fó halálokot az anoxiás/ischaemiás agyi károsodás képezi mint primer károsodás [5]. Számos megjelenési formája ismert: az enyhe neurológiai elváltozásoktól (myoclonusok, különböző fokú kognitív zavarok, lokális vagy generalizált görcsrohamok) a kómáig és az agyhalálig [6]. Az agyi károsodás patomechanizmusában számos folyamat vesz részt: a hypoxia talaján kialakuló kalciumhomeosztázis-zavar, szabad gyökök képződése, proteázkaszkádok és az apoptózis folyamatának beindulása $[7,8]$. Ezek a folyamatok általában a keringés visszatérése utáni órákban és napokban aktiválódnak. Elhúzódó keringésmegállás esetén agyi hipoperfúzió alakul ki akkor is, ha a
1. táblázat

A jelenleg ismert neuroprotekciós lehetőségek az Európai Re suscitatiós Tanács által megadott ajánlásokkal

\begin{tabular}{ll}
\hline $\begin{array}{l}\text { Neuroprotekciós lehetőség } \\
\text { a postresuscitatiós ellátásban }\end{array}$ & Ajánlott célparaméterek \\
\hline A hypoxia és a hyperoxia kerülése & $\begin{array}{l}\text { Az artériás hemoglobin-oxigén- } \\
\text { szaturáció céltartománya: } \\
94-98 \%\end{array}$ \\
A hypocapnia és a hypercapnia & $\begin{array}{l}\text { EtCO }{ }_{2} \text {-monitorozás és a } \\
\text { normocapnia tartása }\end{array}$ \\
Vérülése & Célvércukorérték: <10 mmol/1 \\
Szedáció & $\begin{array}{l}\text { Nincs egyértelmú ajánlás } \\
\text { Nincs egyértelmü ajánlás }\end{array}$ \\
A görcstevékenység kontrollja & $\begin{array}{l}\text { Nincs egyértelmú ajánlás és } \\
\text { bizonyíték }\end{array}$ \\
Neuroprotekciós farmakon & $\begin{array}{l}\text { Olyan artériás középnyomás } \\
\text { tartása, mely mellett a diuresis } \\
\text { megtartott, és a szérumlaktát- } \\
\text { szint csökken. További } \\
\text { tanulmányok szükségesek egyéb } \\
\text { hemodinamikai paraméterek } \\
\text { vizsgálatára }\end{array}$ \\
$32-36{ }^{\circ} \mathrm{C}$ tartása $12-24$ óráig
\end{tabular}

$\mathrm{EtCO}_{2}=$ kilégzésvégi szén-dioxid

mellkaskompressziókkal sikerül megfelelő perfúziós nyomást fenntartani (ezt nevezzük ún. „low-flow” állapotnak), mely mikroinfarktusok kialakulásához vezet. A keringés visszatérése után közvetlenül pár percnyi agyi hyperaemia lép fel, mely az emelkedett perfúziós nyomás és a sérült autoreguláció következménye, és hasonlít a traumás agykárosodás során kialakuló patofiziológiás folyamatokhoz [9]. Valószínúleg ez az oka annak is, hogy a keringés visszatérése után közvetlenül magasan, 100 Hgmm fölött tartott artériás középnyomás nem javította a betegek kimenetelét az alacsonyabb vérnyomáshoz képest, ha azonban az első két órában tartottak fenn magasabb artériás középnyomást, akkor javult a betegek neurológiai kimenetele az alacsonyabb vérnyomású csoporttal összehasonlítva [10]. Fontos még kiemelni azt is, hogy a keringés visszatérése után alkalmazott hyperoxia szintén agyi károsodáshoz vezet. Ennek oka a mitokondriumok sérülése és az oxigén-szabadgyökök fokozott képződése [11].

A másodlagos agyi károsodás megelőzése a postresuscitatiós terápia egyik legfontosabb eleme. Szekunder agykárosodást a keringés visszatérése utáni órákban és napokban számos tényező kiválthat, melyek közül kiemelendő az agyi autoreguláció zavara, az agyi ödéma, a hypo/hyperoxia, a hypo/hypercapnia, az alacsony vérnyomás, a tartósan alacsony vagy magas vércukorérték, a láz, illetve a bármilyen okú hyperthermia. Ugyancsak fokozhatja a károsodás mértékét a nem megfelelő szakszerüséggel végzett postresuscitatiós terápia, amennyiben a fentiek kivédésében funkcióját/célját nem teljesíti.

A postresuscitatiós betegek neurológiai kimenetelét az ún. CPC (cerebral performance category, vagyis az 
2. táblázat |A postresuscitatiós agyi funkció jellemzésére használatos skála

\begin{tabular}{|c|c|}
\hline CPCl Jó agyi teljesítmény & Éber, normális életvitelre képes. \\
\hline $\begin{array}{l}\text { CPC2 Enyhe agyifunkció-csök- } \\
\text { kenés }\end{array}$ & $\begin{array}{l}\text { Éber, kielégítő agyi funkció. } \\
\text { A beteg képes részidős munkát } \\
\text { vállalni megfelelően védett } \\
\text { környezetben, illetve alkalmas } \\
\text { a független életvitelre. }\end{array}$ \\
\hline CPC3 Súlyos agyi károsodás & $\begin{array}{l}\text { Éber, de másoktól függ, önálló } \\
\text { életvitelre nem képes. Kognitív } \\
\text { funkciói limitáltak. }\end{array}$ \\
\hline CPC4 Kóma/vegetatív állapot & $\begin{array}{l}\text { Eszméletlen, nem észleli } \\
\text { környezetét. }\end{array}$ \\
\hline CPC5 Agyhalál & Igazolt agyhalál. \\
\hline
\end{tabular}

$\mathrm{CPC}=$ az agyi teljesítmény kategóriája

agyi teljesítmény kategóriája) klinikai skálával jelzik a legtöbb tanulmányban. Ez alapján a beteg 1-tól 5-ig kategorizálható, ahogy azt a 2. táblázat részletezi. A CPC 1 , 2 kategóriájú betegek jó neurológiai kimenetelüek, míg a CPC 3, 4, 5 rossz neurológiai prognózist jelent.

A postresuscitatiós szívizom-károsodás általában percekkel a keringés visszatérése után detektálható. Jellemzője, hogy reverzibilis, és jól reagál az adekvát terápiára.

A szisztémás ischaemiás-reperfúziós szindróma szepszisszerü állapot, melynek jellemzője a keringés visszatérése utáni első órákban és napokban jelentkező keringési elégtelenség, amely adekvát terápia nélkül a szervek (többek között az agy) hipoperfúzióját és sokszervi elégtelenség kialakulását okozhatja [12].

A keringésmegállás kialakulásáért felelős primer patológiai elváltozás felismerése és kezelése elengedhetetlen ahhoz, hogy a betegek ellátása sikeres legyen.

\section{A normoxia és normocapnia szerepe a postresuscitatiós neuroprotekcióban}

$\mathrm{Az}$ elmúlt évek vizsgálati eredményei rámutattak arra, hogy a megfelelő artériás oxigén- és szén-dioxid-nyomás fontos szereppel bír a neurológiai kimenetel javításában.

Ahogy korábban már említettük, a hypoxia rontotta a neurológiai kimenetelt állatkísérletek során, emellett a hypo- és hypercapnia fennállása rosszabb neurológiai statust idézett elő a betegek kórházi elbocsátásakor [13].

$\mathrm{Az}$ oxigén túladagolása azonban szintén káros, a hyperoxia ugyanis az oxigén-szabadgyökök képzésének kedvez, ami sejtkárosodást és apoptózist von maga után [14].

Kilgannon és mtsai 6326, intenzív osztályos beteg adatait összegezték, akiket három csoportra osztottak: hypoxiás, normoxiás és hyperoxiás csoport [15]. Vizsgálatuk során azt találták, hogy a hyperoxiás csoport kórházi mortalitása sokkal rosszabb volt a normoxiás és a hypoxiás csoporthoz képest. A kórházi túlélők vizsgálatakor pedig arra is fény derült, hogy a hyperoxiás cso- portban sokkal több a rossz neuralis funkciójú beteg a kórházból való elbocsátáskor. Egy másodlagos analízis azt mutatta, hogy az artériás oxigénnyomás $25 \mathrm{Hgmm-}$ nyi emelkedése a fiziológiás érték felett a mortalitás relatív rizikóját 6\%-kal, míg 100 Hgmm-nyi emelkedés 24\%kal növelte [16].

Az Európai Resuscitatiós Tanács ajánlása szerint a postresuscitatiós ellátásban 94-98\%-os oxigénszaturáció elérése a cél, és törekedni kell a hyperoxia elkerülésére [4].

Egy 16542 beteget vizsgáló obszervációs tanulmány az artériás szén-dioxid-nyomás és a kimenetel közti összefüggést vizsgálta postresuscitatiós betegeknél [17]. A betegek ötödénél 24 órán belül észleltek legalább egyszer hypercapniát. A hypocapnia rontotta a mortalitást a normocapniához viszonyítva, hypercapnia esetén azonban nem észlelték ezt a hatást.

Mindkét irányú változás fokozhatja a szekunder agyi károsodás mértékét, ezért az Európai Resuscitatiós Tanács ajánlása alapján a kilégzésvégi szén-dioxid- és a parciális artériás szén-dioxid-nyomás szoros monitorozása, valamint a normocapnia tartása szükséges a postresuscitatiós ellátás során [4].

\section{A vércukor kontrollja mint neuroprotekciós lehetőség}

Újraélesztést követően gyakori jelenség, hogy az agyi glükóztranszport lecsökken, és a neuronok nem jutnak elegendő tápanyaghoz - hiszen az agysejtek elsődleges energiaforrása a glükóz [18]. Ha az agyi perfúzió is csökken, akkor az enyhe hyperglykaemia inkább hasznos lehet, megnövelve a cukor koncentrációs gradiensét.

Számos tanulmány eredménye arra utal, hogy a tartós hyperglykaemia rontja az újraélesztésen átesett betegek neurológiai kimenetelét és mortalitását [19]. Fontos hozzáfüzni azonban, hogy cukorbetegségben szenvedő betegek esetén nem sikerült ilyen összefüggést kimutatni, kivéve, ha extrém hyperglykaemia állt fenn [20].

Kiemelendő továbbá, hogy kritikus állapotú betegek esetén a hypoglykaemiás epizódok kedvezőtlenebbek, mint az enyhe hyperglykaemia, ezért a vércukorszint gyors, hirtelen csökkentése mindenképp kerülendő [21]. Az extrém hypoglykaemia $(<2,0 \mathrm{mmol} / \mathrm{l})$ szignifikáns mortalitásemelkedést okozott intenzív osztályon kezelt, kritikus állapotú betegeknél.

Az Európai Resuscitatiós Tanács ajánlása szerint célszerú $10 \mathrm{mmol} / \mathrm{l}$ alatti vércukorszintet tartani ebben a betegcsoportban a hypoglykaemiás epizódok szigorú kerülésével [4].

\section{Szedáció és a görcstevékenység kezelése}

A szedáció fontos elemét képezi az akut agykárosodáson átesett betegek, így a sikeresen újraélesztett betegek terápiájának is. A szedáció védelmet nyújt egyrészt az elsőd- 
leges agyi károsodás további kiterjedése, másrészt a szekunder agykárosodás kialakulása ellen [22]. Arra azonban még nincs bizonyíték, hogy a postresuscitatiós terápiában milyen szedatívum adagolása a leghatékonyabb, mennyi ideig szükséges a betegek szedációjának alkalmazása, illetve a szedáció maga befolyásolja-e ezen betegek kimenetelét.

A leggyakrabban szedációra alkalmazott szerek az opioidok és a hipnotikumok. Célszerü lenne a rövid felezési idejü ágensek használata, mint például propofol, remifentanil vagy alfentanil [23].

A szedáció mindemellett fontos elemét képezi a hőmérsékletkontrollnak, csökkenti ugyanis az alacsonyabb hőmérséklet következtében kialakuló remegés mértékét (mely metabolikus krízist jelent a szervezet számára), a sejtek oxigénfelhasználását, az agyi tevékenység mértékét és a betegek agitáltságát [22]. A remegés mértékének csökkentésére számos centrumban izomrelaxánst is alkalmaznak, ennek több mint egynapos használata azonban számos szövődményhez vezethet: elfedheti a görcstevékenységet, jelentős mérvü izomgyengeséget okozhat, és ezáltal megnyújthatja a betegek gépi lélegeztetésének és intenzív osztályos tartózkodásának hosszát. Kiemelendő, hogy amennyiben mégis szükséges az alkalmazása, azt mindenképp EEG-alapú monitorozással kell kiegészíteni, hogy felismerjük az esetleges görcstevékenységet.

Az újraélesztésen átesett betegek jelentős részénél tapasztalható valamilyen mértékű görcstevékenység, mely az agyi metabolikus rátát nagymértékben megemelheti, ezért hatékony kontrollja elengedhetetlen. Klinikai manifesztációja széles skálán mozog: az enyhe myoclonusoktól kezdve a generalizált tónusos-klónusos görcsrohamig. Akut posthypoxiás myoclonus az esetek 18-25\%-ában jelentkezik az ellátás első 24 órájában, pontos patofiziológiáját és prognosztikai hatását azonban még ma sem ismerjük [24]. Arra sincs elég adatunk, hogy a görcstevékenység ellátására melyik görcsgátló használata a leghatékonyabb a postresuscitatiós terápiában, így nincs egyértelmú irányelv arra vonatkozóan, hogy melyik antiepileptikum használata javasolt ebben a betegcsoportban [25].

\section{Neuroprotekciót segítő gyógyszerek}

Egyelőre nincs egyértelmű bizonyíték arra vonatkozóan, hogy létezik-e olyan gyógyszer, amely valóban segíti a postresuscitatiós neuroprotekciót, ám ígéretesnek mutatkozó eredmények már napvilágot láttak egyes farmakológiai ágenseket illetőn. Az eddig végzett legtöbb ilyen vizsgálat állatkísérletes, és csak pár klinikai adat áll rendelkezésünkre.

A xenon az egyik leggyakrabban tanulmányozott szer, mely a postresuscitatiós neuroprotekcióban beválhat. Preklinikai vizsgálatok azt mutatták, hogy megelőzheti és mérsékelheti az ischaemiás-reperfúziós agyi károsodást [26]. Egy randomizált klinikai vizsgálat 110, kórhá- zon kívüli újraélesztésen átesett beteget bevonva vizsgálta a xenon hatását. A betegek egy része terápiás hypothermiában és xenonkezelésben is részesült, míg a kontrollcsoportnál csak terápiás hypothermiát alkalmaztak. Sem a neurológiai kimenetel, sem a hat hónapos túlélés nem különbözött a két csoportban, azonban sokkal kevesebb fehérállományi károsodás mutatkozott az agyi MR-kontroll során a xenonnal kezelt betegek esetében [27]. Ezek függvényében további klinikai vizsgálatok szükségesek a xenon hatékonyságának bizonyítására. A terápia hátránya, hogy jelentős többletköltséget jelent, és a xenon tárolása speciális felszerelést igényel.

$\mathrm{Az}$ eritropoetin neuroprotekciós hatását is vizsgálták több tanulmányban. Egy szintén kórházon kívüli újraélesztésen átesett betegeket bevonó vizsgálat azonban nem mutatta ki a korán alkalmazott, nagy dózisú eritropoetin előnyét, sőt a kezelt csoportban megnőtt a trombotikus szövődmények száma [28].

A rozuvasztatin patkányokon végzett kísérletekben javította a sikeresen újraélesztett állatok túlélését, szívizomfunkcióját és neurológiai felépülését [29]. Hatékonyságának bizonyítására azonban még további vizsgálatok szükségesek.

Az egyik legígéretesebbnek mutatkozó farmakológiai ágens a B-vitaminok csoportjába tartozó tiamin, mely nélkülözhetetlen a neuronok megfelelő múködéséhez. Újraélesztett egereken végzett kísérletek során azt találták, hogy a tíznapos túlélés és neurológiai kimenetel jelentősen jobb volt a tiaminnal kezelt csoportban. Az egerek agyából végzett szövettani vizsgálat azt mutatta, hogy a tiaminnal kezelt egerekben csökkent az agyi károsodás mértéke. A vizsgálat klinikai része során sikeresen újraélesztett betegek piruvát-dehidrogenáz-aktivitását hasonlították össze egészséges önkéntesekével, és azt találták, hogy újraélesztés alatt a piruvát-dehidrogenázaktivitás jelentősen csökken. A tiamin a piruvát-dehidrogenázt szabályozó kofaktorként múködik a citrátciklusban. További vizsgálatok szükségesek annak tisztázására, hogy a tiamin milyen dózisban lehet a leghatékonyabb, és pontosan milyen klinikai hatásokat eredményez a sikeresen újraélesztett betegekben [30].

$\mathrm{Az}$ inhalációs anesztetikumok közül a xenon mellett az izoflurán és a szevoflurán merült fel mint a postresuscitatiós neuroprotekció lehetséges szerei. Állatkísérletek igazolták a myocardiumra kifejtett protektív hatásukat, de a neuroprotekcióban betöltött szerepük nem ennyire egyértelmű [31]. További preklinikai vizsgálatok szükségesek, hogy bizonyítsák esetleges pozitív hatásukat ebben a betegcsoportban.

\section{Az agyi perfúzió védelme}

Az adekvát agyi perfúzió fenntartása elengedhetetlen a további szekunder agykárosodás megelőzésében. Az autoreguláció sérülése miatt az agyi perfúzió nagyban függ a hemodinamikai paraméterektől és az artériás középnyomástól. A postresuscitatiós szindróma részeként va- 
sodilatatio, myocardialis diszfunkció és ezek következményeként jelentős hemodinamikai instabilitás alakulhat ki. A célhőmérséklet-orientált kezelés során alkalmazott alacsonyabb hőmérséklet ezt a hemodinamikai instabilitást tovább fokozhatja, mivel a vasoconstrictio erôsödéséhez vezet ugyan, de ezzel együtt a perctérfogat csökkenését is okozza. Mindehhez hozzájárul, hogy hypothermia hatására a beteg diuresise fokozódik, ami a hypovolaemia kialakulásának kedvez. Ezek alapján az a következtetés vonható le, hogy a sikeresen reanimált betegek hemodinamikai paramétereinek minél előbbi rendezése és folyamatos monitorozása alapvető része a neuroprotekciós stratégiáknak.

Egy klinikai tanulmány azt vizsgálta, hogy közvetlenül a keringés visszatérése után milyen gyakoriságú és milyen mértékű hipotenzió volt észlelhető, és ennek volt-e hatása a kimenetelre [32]. A vizsgált betegek 47\%-nál észleltek hipotenziós epizódot azok intenzív osztályos felvételekor, és ezen betegek 2/3-a nem élte túl a kórházi tartózkodást. Ezzel szemben abban a csoportban, amelyikben nem észleltek hipotenziós epizódot az intenzív osztályos felvételkor, a betegek 63\%-a élve hagyta el a kórházat.

Egyelőre azonban nem sikerült egyértelműen meghatározni azt a vérnyomáscélértéket, amelyet a postresuscitatiós ellátásban tartani szükséges. Egy újabb vizsgálat ugyanis épp az ellenkezójét találta, vagyis a magasabb vérnyomású csoportban rosszabb volt a betegek túlélése az alacsonyabb vérnyomású csoporthoz képest [33].

Egyértelmû́ adatok hiányában az Európai Resuscitatiós Tanács azt javasolja, hogy olyan vérnyomásértéket célozzunk meg a postresuscitatiós terápiában, mely mellett megtartott a betegek diuresise, és szérumlaktátszintjük csökken, illetve normalizálódik [4]. Ezek a paraméterek a szervperfúzió javulásának jelei.

Tekintettel arra, hogy önmagában a vérnyomás monitorozása nem ad egyértelmú és teljes képet a betegek keringésének valódi állapotáról, felmerül a kérdés, hogy egy magasabb szintű hemodinamikai monitorozás és az ezáltal vezérelt terápia összetettebb képet ad-e a makrocirkulációról és ezáltal a szervek, többek közt az agy perfúziójáról, valamint ennek alkalmazása befolyásolja-e a betegek kimenetelét.

Az egyik legkézenfekvőbb eszköz a szívultrahang, mely nem invazív vizsgálat, és alkalmazásával könnyen megállapítható a szív pumpafunkciója, a volumenstatus indirekt jelei, valamint a perctérfogat. Hátránya, hogy folyamatos monitorozásra nem alkalmas, és használata megfelelő képzettséget igényel. Az oesophagus-Doppler-monitor alkalmazása egyszerúbb, egyelőre azonban nem igazán terjedt el a magyar gyakorlatban.

$\mathrm{Az}$ arteria (a.) pulmonalis katéter az egyik legpontosabb mérési módszer, melynek segítségével a perctérfogat és az egyéb hemodinamikai paraméterek, valamint a szöveti perfúzió meghatározható. Hátránya azonban, hogy ez az egyik leginvazívabb monitorizálóeszköz. Az Európai Intenzív Terápiás Társaság 2015-ben megjelent, hemodinamikai monitorozásról szóló ajánlása nem javasolja az a. pulmonalis katéter rutinalkalmazását sokk esetén, ha nem áll fenn jobbszívfél-elégtelenség [34].

A postresuscitatiós ellátásban korábban már validálták a thermodilutiós technikán és a pulzuskontúr-analízisen alapuló PiCCO ${ }^{\mathrm{TM}}$ (Pulse index Contour Cardiac Output) monitort [35]. Igazolták, hogy az újraélesztés után alkalmazott enyhe terápiás hypothermia ellenére (32-34 $\left.{ }^{\circ} \mathrm{C}\right)$ az eszköz pontosan mér, és használható ebben a betegcsoportban. A PiCCO ${ }^{\mathrm{TM}}$ volumetriás monitor előnye, hogy kevésbé invazív, mint az a. pulmonalis katéter, könnyebben használható, és kisebb a behelyezéséből származó szövődmények száma, de emellett szintén számos információt ad a betegek hemodinamikájáról: meghatározható a perctérfogat, a szív pumpafunkciója, a szisztémás vascularis rezisztencia és ezáltal az erek vasodilatatiójának mértéke, valamint a beteg folyadékkal való töltöttségi állapota.

Saját klinikai vizsgálatunkban mi is tanulmányoztuk a $\mathrm{PiCCO}^{\mathrm{TM}}$ monitor és az azáltal vezérelt terápia hatékonyságát a postresuscitatiós terápiában. Előzetes eredményeink azt mutatták, hogy a PiCCO $^{\mathrm{TM}}$ monitor használatának van létjogosultsága a postresuscitatiós ellátásban [36]. A PiCCO ${ }^{\mathrm{TM}}$-val mért hemodinamikai paraméterek (szívindex, szisztémás vascularis rezisztencia) (1. ábra) az ellátás első 48 órájában hasonló válto-
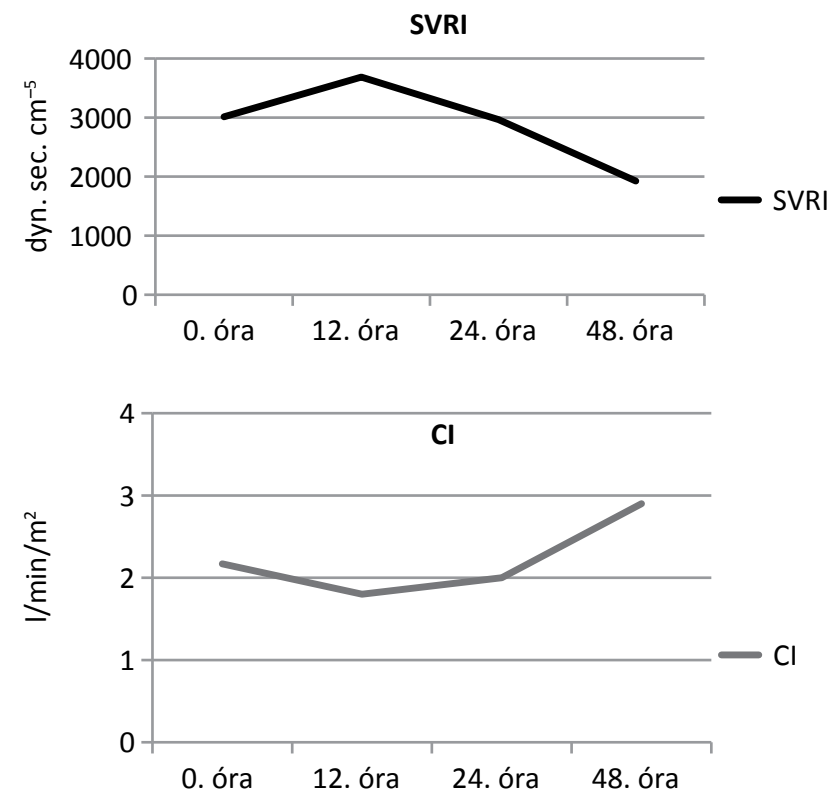

1. ábra $\mid$ A szisztémás vascularis ellenállási index és a szívindex változása a célhőmérséklet-orientált kezelés során (betegszám: $\mathrm{n}=28$ ). A betegek a 0 . és 48 . óra alatt normothermiásak, míg a 12 . és 24. óra mérései alatt hypothermiásak voltak. Az ábrán jól látható, hogy a szisztémás vascularis ellenállás szignifikánsan változott a hőmérséklet módosulásával: magasabb volt hypothermia alatt a normothermia során mért értékekhez képest (Friedmanteszt: $\mathrm{p}<0,001)$. A szívindex szintén szignifikáns változást mutatott a különböző hőmérsékleten történt mérések során: alacsonyabb hőmérsékleten alacsonyabb szívindexet mértünk (Friedman-teszt: $\mathrm{p}<0,001$ )

CI = szívindex $;$ SVRI = szisztémás vascularis ellenállási index 
zást mutattak, mint amilyet már korábban is mértek a. pulmonalis katéterrel sikeres újraélesztés után [37]. Anynyit fontosnak tartunk megjegyezni, hogy a $\mathrm{PiCCO}^{\mathrm{TM}}$ alkalmazása során nem kapunk adatot a pulmonalis rezisztenciáról, szemben az a. pulmonalis katéterrel történt mérésekkel. Emellett azt találtuk, hogy a $\mathrm{PiCCO}^{\mathrm{TM}}$ által monitorizált betegcsoportban kevesebbszer használtuk három katecholamin kombinációját, ami alapján azt a következtetést vontuk le, hogy a katecholaminok adekvát adagolásában segít a magasabb szintű hemodinamikai monitorozás alkalmazása. További vizsgálatokat és az elemszám növelését tervezzük annak érdekében, hogy bizonyítsuk a $\mathrm{PiCCO}^{\mathrm{TM}}$ valós létjogosultságát, és esetlegesen megtaláljuk azokat a hemodinamikai paramétereket, melyek segítségével a szervek perfúziója minél inkább nyomon követhető.

\section{Célhőmérséklet-orientált kezelés}

A terápiás hypothermia, mint a postresuscitatiós neuroprotekció egyik legfontosabb eleme, a 2000-es évek elején került be az újraélesztési ajánlásokba. Ennek alapját két tanulmány képezte, melyek során sikeresen újraélesztett, eszméletlen betegeket vizsgáltak. A kezelés során azt tapasztalták, hogy a 32-34 ${ }^{\circ} \mathrm{C}$-ra lehütött betegek neurológiai kimenetele és a betegek túlélése jobb volt a standard, normothermiás terápiához képest [38, 39].

Az elmúlt tíz évben az enyhe terápiás hypothermia jelentette az egyetlen olyan postresuscitatiós terápiás lépést, melyre valódi bizonyíték a rendelkezésünkre áll. Az ajánlások azt javasolták, hogy minden eszméletlen, kórházon kívül sikeresen újraélesztett betegnél, akinél sokkolandó ritmus állt fenn kezdeti ritmuszavarként, 32-34 ${ }^{\circ} \mathrm{C}$-os hypothermiás kezelés alkalmazása szükséges. Amennyiben kórházon belüli keringésmegállás történt, vagy a kezdeti ritmus nem volt sokkolandó, szintén megfontolandónak tartották a terápiás hypothermiát [40]. Sok kérdés maradt azonban továbbra is nyitott. Fontos szempont ezek közül, hogy mikor kezdjük a hypothermiás kezelést, milyen hosszan alkalmazzuk, valójában hány ${ }^{\circ} \mathrm{C}$-os hőmérsékletet célozzunk. Annak a meghatározása is szükséges, hogy egyáltalán minden betegcsoportot azonos körülmények között kezeljünk-e. Ezen kérdések megválaszolása azért fontos, mert egyrészt a terápia hatékonysága fokozható lenne, másrészt kiemelendő, hogy a hypothermia számos mellékhatással is rendelkezik.

Ami a célhőmérsékletet illeti, abban vagyunk biztosak, hogy a láz az ellátás első pár napjában biztosan káros. A fent említett két tanulmányban a rosszabb kimenetelú, standard terápiával kezelt kontrollcsoport betegeinek egy része lázas volt.

Egy újabb áttörést a terápiás hypothermiás kezelésben a 2013-ban megjelent, ún. TTM- (targeted temperature management - célhőmérséklet-orientált kezelés) tanulmány jelentette [41], mely alapján az Európai Resuscitatiós Tanács a 2015-ös ajánlásában a célhőmérsékletet
32-36 ${ }^{\circ} \mathrm{C}$-ra módosította, és a terápiás hypothermia helyett a „célhőmérséklet-orientált kezelés” kifejezés használatát javasolta [4]. Fontos kiemelni, hogy ez a célhőmérséklet továbbra sem azt jelenti, hogy a betegeket normothermiával kezeljük, és a hőmérsékletkontroll lazábbá vált, hanem elegendő lehet a betegek $36{ }^{\circ} \mathrm{C}$-ra való hütése.

A TTM-tanulmány randomizált, kontrollált, multicentrikus vizsgálat, melynek alapja, hogy 950, kórházon kívül újraélesztett beteget osztottak két csoportra az alapján, hogy hány ${ }^{\circ} \mathrm{C}$-os hőmérséklet-kezelést alkalmaztak náluk: a betegek egy részét $33{ }^{\circ} \mathrm{C}$-os, másik részét pedig $36{ }^{\circ} \mathrm{C}$-os terápiának vetették alá. A vizsgálat eredménye azt mutatta, hogy az alacsonyabb hőmérséklet nem eredményezett jobb kimenetelt, mind a magasabb. A tanulmányt számos kritika érte, és egyértelmű következtetést továbbra sem sikerült levonni a célhőmérsékletet illetően. A vizsgálat eredményeivel és kritikáival lapszámunk egy külön közleményben foglalkozik, így azokat ott részletezzük.

$\mathrm{Az}$ Amerikai Neurológiai Akadémia (American Academy of Neurology) 2017-ben megjelent ajánlása kicsit pontosabb irányelveket fogalmaz meg a postresuscitatiós hőmérséklet-terápiát illetően [42]. Azoknál a sikeresen reanimált, eszméletlen betegeknél, akiknél kezdetben sokkolandó ritmust észleltek, továbbra is 32$34{ }^{\circ} \mathrm{C}$-os hőmérséklet-terápiát javasol 24 óráig. A kezdeti ritmustól függetlenül megfontolható a $36^{\circ} \mathrm{C}$-os terápia alkalmazása is 24 órán keresztül. Ezután 8 óra alatti felmelegedés javasolt $37{ }^{\circ} \mathrm{C}$-ra, ezt követően pedig a betegek hőmérséklete 72 óráig maximum $37,5{ }^{\circ} \mathrm{C}$-on tartható. Azt is kimondja, hogy amennyiben a kezdeti ritmus nem sokkolandó, az alacsonyabb hőmérséklet-kezelés valószínúleg hatékonyabb, mint a normothermia.

Felmerült a kérdés, hogy a prehospitálisan elkezdett célhőmérséklet-orientált kezelés nem hatékonyabb-e a később, kórházi felvétel után indított kezelésnél. Az eddigi adatok azt támasztják alá, hogy nem javasolt a kórházon kívüli hütés, mivel nem javította a kimenetelt, ellenben számos mellékhatással járhat [43]. Ennek egyik magyarázata a postresuscitatiós agyi károsodás mechanizmusának komplexitása, számos folyamat ugyanis órákkal a keringésmegállás után zajlik le.

A hypothermia neuroprotektív hatása komplex élettani mechanizmusok által jön létre. Egyrészt minden egyes ${ }^{\circ} \mathrm{C}$-csökkenés az agyi metabolikus ráta 6\%-os mérséklődését jelenti. Emellett csökken az excitatorikus neurotranszmitterek szintje, az agyban lejátszódó apoptózis mértéke, javul az agyi mikrocirkuláció, és csökken az intracranialis nyomás.

A hőmérséklet-terápia kivitelezése többféle módon lehetséges: fizikális hûtés (például jégzselék használata), külső hűtőtakarók hőmérséklet-visszajelző rendszerrel (2. ábra), intravascularis hütés. Nincs ajánlás arra, hogy melyik módszer alkalmazása javasolt, és nincs bizonyíték arra, hogy valamelyik eljárás hatékonyabb a másiknál. 


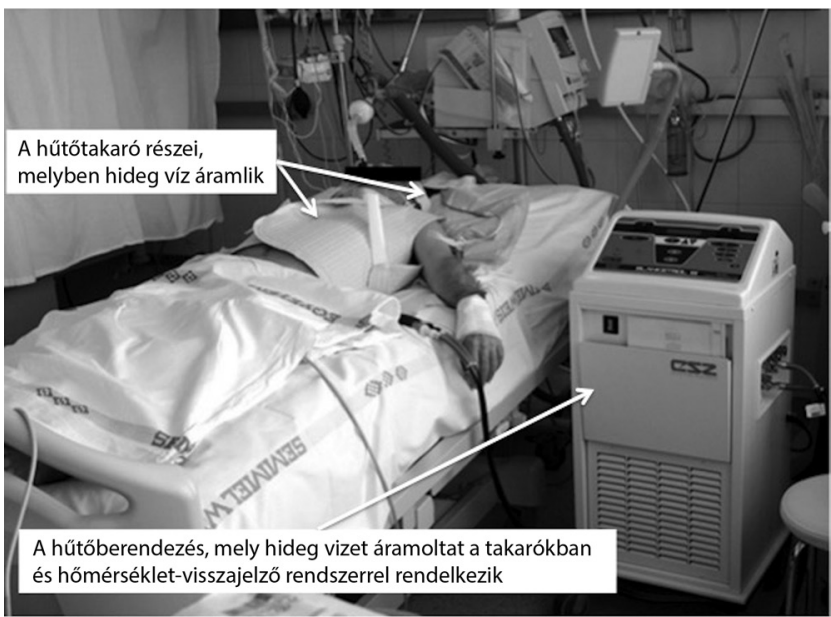

2. ábra

Külső, hőmérséklet-visszajelző rendszerrel múködő hűtőtakaró használata intézetünkben

A hűtési folyamat három fázisból áll: iniciáció, a célhőmérséklet fenntartása, visszamelegítés. Az iniciáció 30 $\mathrm{ml} / \mathrm{kg}$ krisztalloiddal történik, melyet a fenntartási fázis követ az előbb említett eszközök valamelyikével. A hőmérséklet-terápia lejártával indul a felmelegítés passzív módszerrel, 0,25 ${ }^{\circ} \mathrm{C} /$ óra sebességgel. Egy folyamatban levő vizsgálatban éber betegeknél végeznek $33{ }^{\circ} \mathrm{C}$-ra hưtést intravénás katéterrel 6 órán keresztül, majd $1{ }^{\circ} \mathrm{C} /$ óra aktív melegítéssel 3 óra alatt normalizálják a testhőt, ami mellett eddig káros mellékhatásról nem számoltak be a melegítéssel kapcsolatban.

\section{Következtetés}

A sikeres újraélesztés utáni morbiditás és mortalitás még mindig magas, aminek fó komponense a postresuscitatiós agyi károsodás. Emiatt a neuroprotekció képezi a postresuscitatiós ellátás legfontosabb elemét. Mai ismereteink szerint a postresuscitatiós agyi védelem két fó irányvonala a primer agykárosodás kiterjedésének kivédése és a szekunder agykárosodás kialakulásának megelőzése. Egyelőre kevés, valóban bizonyított eljárás áll rendelkezésünkre, és számos kérdés áll megválaszolatlanul, melyek tisztázására további vizsgálatok elvégzése szükséges.

Jelenlegi tudásunk és az eddig rendelkezésre álló adatok alapján a postresuscitatiós neuroprotekciót az alábbi módszerekkel fokozhatjuk:

- a normoxia (cél-SpO 2 :94-98\%) és a normocapnia tartása;

- célvércukorérték a postresuscitatiós ellátásban: <10 mmol/l és a hypoglykaemia szigorú kerülése;

- szedáció és a görcstevékenység szoros kontrollja, lehetőség szerint EEG-monitorozással;

- az agyi perfúzió fenntartása a hemodinamikai paraméterek szoros monitorozása mellett;

- célhőmérséklet-orientált kezelés: 32-36 ${ }^{\circ} \mathrm{C}$ elérése és fenntartása 12-24 órán keresztül, majd normothermia fenntartása min. 72 órán át.
Anyagi támogatás: A közlemény megírása és az ahhoz kapcsolódó munka anyagi támogatásban nem részesült.

Szerzői munkamegosztás: K. E.: Az anyag kidolgozása, szakirodalmi másodelemzés, a kézirat szövegezése. G. L.: A kézirat szakmai lektorálása. M. B.: A kézirat szakmai lektorálása. Z. E.: Az anyag kidolgozása, szakirodalmi másodelemzés, a kézirat szövegezése. A cikk végleges változatát mindegyik szerző elolvasta és jóváhagyta.

Érdekeltségek: A szerzőknek nincsenek érdekeltségeik.

\section{Irodalom}

[1] Berdowski J, Berg RA, Tijssen JG, et al. Global incidences of out-of-hospital cardiac arrest and survival rates: systematic review of 67 prospective studies. Resuscitation 2010; 81: 1479-1487.

[2] Perkins GD, Handley AJ, Koster RW, et al. European Resuscitation Council Guidelines for Resuscitation 2015: Section 2. Adult basic life support and automated external defibrillation. Resuscitation 2015; 95: 81-99.

[3] Nagy F, Szabó-Némedi N. Resuscitation guidelines of the European Resuscitation Council and the Hungarian Resuscitation Council 2015. [Az Európai Resuscitatiós Társaság (ERC) és a Magyar Resuscitatiós Társaság (MRT) Újraélesztés Ajánlása 2015.] Magy Mentésügy 2015; 2: 6-34. [Hungarian]

[4] Nolan JP, Soar J, Cariou A, et al. European Resuscitation Council and European Society of Intensive Care Medicine Guidelines for Post-resuscitation Care 2015. Section 5 of the European Resuscitation Council Guidelines for Resuscitation 2015. Resuscitation 2015; 95: 202-222.

[5] Laver S, Farrow C, Turner D, et al. Mode of death after admission to an intensive care unit following cardiac arrest. Intensive Care Med. 2004; 30: 2126-2128.

[6] Krumholz A, Stern BJ, Weiss HD. Outcome from coma after cardiopulmonary resuscitation: relation to seizures and myoclonus. Neurology 1988; 38: 401-405.

[7] Bano D, Nicotera P. $\mathrm{Ca}^{2+}$ signals and neuronal death in brain ischemia. Stroke 2007; 38: 674-676.

[8] Pulsinelli WA. Selective neuronal vulnerability: morphological and molecular characteristics. Prog Brain Res. 1985; 63: 29-37.

[9] Sundgreen C, Larsen FS, Herzog TM, et al. Autoregulation of cerebral blood flow in patients resuscitated from cardiac arrest. Stroke 2001; 32: 128-132.

[10] Müllner M, Sterz F, Binder M, et al. Arterial blood pressure after human cardiac arrest and neurological recovery. Stroke 1996; 27: 59-62.

[11] Vereczki V, Martin E, Rosenthal RE, et al. Normoxic resuscitation after cardiac arrest protects against hippocampal oxidative stress, metabolic dysfunction, and neuronal death. J Cereb Blood Flow Metab. 2006; 26: 821-835.

[12] Adrie C, Adib-Conquy M, Laurent I, et al. Successful cardiopulmonary resuscitation after cardiac arrest as a "sepsis-like" syndrome. Circulation 2002; 106: 562-568.

[13] Helmerhost HJ, Roos-Bloom MJ, van Westerloo DJ, et al. Associations of arterial carbon dioxide and arterial oxygen concentrations with hospital mortality after resuscitation from cardiac arrest. Crit Care 2015; 19: 348.

[14] Becker LB. New concepts in reactive oxygen species and cardiovascular reperfusion physiology. Cardiovasc Res. 2004; 61: 461470.

[15] Kilgannon JH, Jones AE, Shapiro NI, et al. Association between arterial hyperoxia following resuscitation from cardiac arrest and in-hospital mortality. JAMA 2010; 303: 2165-2171.

[16] Kilgannon JH, Jones AE, Parrillo JE, et al. Relationship between supranormal oxygen tension and outcome after resuscitation from cardiac arrest. Circulation 2011; 123: 2717-2722. 
[17] Schneider AG, Eastwood GM, Bellomo R, et al. Arterial carbon dioxide tension and outcome in patients admitted to the intensive care unit after cardiac arrest. Resuscitation 2013; 84: 927934.

[18] Wang CH, Huang $\mathrm{CH}$, Chang WT, et al. Associations between blood glucose level and outcomes of adult in-hospital cardiac arrest: a retrospective cohort study. Cardiovasc Diabetol. 2016; 15: 118 .

[19] Beiser DG, Carr GE, Edelson DP, et al. Derangements in blood glucose following initial resuscitation from in-hospital cardiac arrest: a report from the national registry of cardiopulmonary resuscitation. Resuscitation 2009; 80: 624-630.

[20] Egi M, Bellomo R, Stachowski E, et al. Blood glucose concentration and outcome of critical illness: the impact of diabetes. Crit Care Med. 2008; 36: 2249-2255.

[21] Arabi YM, Tamim HM, Rishu AH. Hypoglycemia with intensive insulin therapy in critically ill patients: predisposing factors and association with mortality. Crit Care Med. 2009; 37: 25362544.

[22] Dell'Anna AM, Taccone FS, Halenarova K, et al. Sedation after cardiac arrest and during therapeutic hypothermia. Minerva Anestesiol. 2014; 80: 954-962.

[23] Bjelland TW, Dale O, Kaisen K, et al. Propofol and remifentanil versus midazolam and fentanyl for sedation during therapeutic hypothermia after cardiac arrest: a randomised trial. Intensive Care Med. 2012; 38: 959-967.

[24] Crepeau AZ, Britton JW, Fugate JE, et al. Electroencephalography in survivors of cardiac arrest: comparing pre- and post-therapeutic hypothermia eras. Neurocrit Care 2015; 22: 165-172.

[25] Gupta HV, Caviness JN. Post-hypoxic myoclonus: current concepts, neurophysiology, and treatment. Tremor Other Hyperkinet Mov. 2016; 6: 409.

[26] Wilhelm S, Ma D, Maze M, et al. Effects of xenon on in vitro and in vivo models of neuronal injury. Anesthesiology 2002; 96: 1485-1491.

[27] Laitio R, Hynninen M, Arola O, et al. Effect of inhaled xenon on cerebral white matter damage in comatose survivors of out-ofhospital cardiac arrest: a randomized clinical trial. JAMA 2016; 315: 1120-1128.

[28] Cariou A, Deye N, Vivien B, et al. Early high-dose erythropoietin therapy after out-of-hospital cardiac arrest: a multicenter, randomized controlled trial. J Am Coll Cardiol. 2016; 68: 40-49.

[29] Qiu Y, Wu Y, Meng M, et al. Rosuvastatin improves myocardial and neurological outcomes after asphyxial cardiac arrest and cardiopulmonary resuscitation in rats. Biomed Pharmacother. 2017; 87: 503-508

[30] Ikeda K, Liu X, Kida K, et al. Thiamine as a neuroprotective agent after cardiac arrest. Resuscitation 2016; 105: 138-144.

[31] Moore JC, Bartos JA, Matsuura TR, et al. The future is now: neuroprotection during cardiopulmonary resuscitation. Curr Opin Crit Care 2017; 23: 215-222.
[32] Trzeciak S, Jones AE, Kilgannon JH, et al. Significance of arte rial hypotension after resuscitation from cardiac arrest. Crit Care Med. 2009; 37: 2895-2903.

[33] Bro-Jeppesen J, Annborn M, Hassager C, et al. Hemodynamics and vasopressor support during targeted temperature management at $33{ }^{\circ} \mathrm{C}$ versus $36^{\circ} \mathrm{C}$ after out-of-hospital cardiac arrest: a post hoc study of the target temperature management trial. Crit Care Med. 2015; 43: 318-327.

[34] Cecconi M, De Backer D, Antonelli M, et al. Consensus on circulatory shock and hemodynamic monitoring. Task force of the European Society of Intensive Care Medicine. Intensive Care Med. 2014; 40: 1795-1815.

[35] Tagami T, Kushimoto S, Tosa R, et al. The precision of PiCCO ${ }^{\circledR}$ measurements in hypothermic post-cardiac arrest patients. Anaesthesia 2012; 67: 236-243.

[36] Kovács E, Pilecky D, Szudi G, et al. The use of invasive hemodynamic monitoring during post-resuscitation therapeutic hypothermia (preliminary data). [Az invazív hemodinamikai monitorozás szerepe a súlyos állapotú postresuscitatiós betegek ellátásában (előzetes adatok).] Cardiol Hung. 2015; 45: 90-95. [Hungarian]

[37] Oksanen T, Skrifvars M, Wilkman E. et al. Postresuscitation hemodynamics during therapeutic hypothermia after out-ofhospital cardiac arrest with ventricular fibrillation: a retrospective study. Resuscitation 2014; 85: 1018-1024.

[38] Hypothermia after Cardiac Arrest Study Group. Mild therapeutic hypothermia to improve the neurologic outcome after cardiac arrest. N Engl J Med. 2002; 346: 549-556. Correction: N Engl J Med. 2002; 346: 1756

[39] Bernard SA, Gray TW, Buist MD, et al. Treatment of comatose survivors of out-of-hospital cardiac arrest with induced hypothermia. N Engl J Med. 2002; 346: 557-563.

[40] Nolan JP, Deakin CD, Soar J, et al. European Resuscitation Council Guidelines for Resuscitation 2005: Section 4. Adult advanced life support. Resuscitation 2005; 67(Suppl 1): S39-S86.

[41] Nielsen N, Wetterslev J, Cronberg T, et al. Targeted temperature management at $33^{\circ} \mathrm{C}$ versus $36^{\circ} \mathrm{C}$ after cardiac arrest. N Engl J Med. 2013; 369: 2197-2206.

[42] Geocadin RG, Wijdicks E, Armstrong MJ, et al. Practice guideline summary: reducing brain injury following cardiopulmonary resuscitation. Report of the Guideline Development, Dissemination, and Implementation Subcommittee of the American Academy of Neurology. Neurology 2017; 88: 2141-2149.

[43] Arrich J, Holzer M, Havel C, et al. Pre-hospital versus in-hospital initiation of cooling for survival and neuroprotection after outof-hospital cardiac arrest (Review). Cochrane Database Syst Rev. 2016; 3: CD010570

(Kovács Enikő dr.,

Budapest, Városmajor u. 68., 1122 e-mail: kovacs.eniko2@med.semmelweis-univ.hu)

A cikk a Creative Commons Attribution 4.0 International License (https://creativecommons.org/licenses/by/4.0/) feltételei szerint publikált Open Access közlemény melynek szellemében a cikk bármilyen médiumban szabadon felhasználható, megosztható és újraközölhetö, feltéve, hogy az eredeti szerző és a közlés helye, illetve a CC License linkje és az esetlegesen végrehajtott módosítások feltüntetésre kerülnek. (SID_1) 